\title{
120. Investigation of Corroded Ancient Glasses by X-ray Diffraction
}

\author{
By Kazuo Yamasaki*) and Yoshihiko SAITo**) \\ (Comm. by Y. SHIBATA, M.J.A., Oct. 12, 1960)
}

Ancient glass objects, especially those which have been excavated from the soil are frequently incrusted with corrosion products. Although numerous reports have been published on the chemical compositions of ancient glasses, there seems to be no X-ray study on their corrosion products. In the course of chemical studies on the ancient Chinese and Japanese glass objects we had a chance to examine their corrosion products by X-ray. These glass objects are made of two kinds of glass, alkali-lime glass and lead glass. The former was resistant to corrosion and had only a thin corrosion layer which gave no definite diffraction patterns because of the amorphous nature. Only in a few cases the presence of quartz or cristobalite was recognized. On the other hand objects made of lead glass were liable to corrosion and they were always covered with thick corrosion layers which proved to be lead carbonate, sulfate or, in some cases, phosphate.

Experimental procedure. The specimens for X-ray diffraction were taken cautiously from the corroded surface of glass objects examined. A commercial camera of $57.3 \mathrm{~mm}$ in diameter was used for taking $\mathrm{X}$-ray diffraction photographs. Copper $\mathrm{K}$ or iron $\mathrm{K}$ radiation was used. Each specimen was so small in amount that it was used without grinding for taking diffraction photographs. The specimen support was a fine glass fiber of $0.2 \mathrm{~mm}$ in diameter and $15 \mathrm{~mm}$ in length drawn from a borosilicate glass rod. The specimen powder was held on one end of the fiber by a very small amount of grease. The minimum required amount of the specimen was about $0.000,01 \mathrm{~g}$ and this amount was found to be enough to give clear diffraction patterns. The X-ray diffraction photographs taken were compared with the data given in standard references and corrosion products were identified in normal way. ${ }^{1)}$

Glass objects examined and the results. The glass objects used in this study are a part of those which Dr. Umehara placed at our disposal. All the objects were corroded, one (no. 3 in Table I) superficially and others severely. The glass objects and lead compounds identified are listed in Tables I and II.

*) Chemical Institute, Science Faculty, Nagoya University.

**) Institute for Solid State Physics, University of Tokyo. 
Table I

\begin{tabular}{|c|c|c|}
\hline \multicolumn{2}{|r|}{ Glass objects } & Corrosion product identified \\
\hline 1 & $\begin{array}{l}\text { Ritual disc, pi. Warring States } \\
\text { period. This disc belongs to the } \\
\text { Eguchi Collection. }\end{array}$ & Lead carbonate and sulfate \\
\hline 2 & $\begin{array}{l}\text { Cicada which was put into the } \\
\text { mouth of a corpse. } 3 \mathrm{~cm} \text { in } \\
\text { length. Han or pre-Han period }\end{array}$ & Lead phosphate \\
\hline $3^{*}$ & $\begin{array}{l}\text { Mirror. } 4 \mathrm{~cm} \text { in diameter. This } \\
\text { mirror belongs to the Moriya } \\
\text { Collection. }\end{array}$ & Lead carbonate \\
\hline $4 *$ & $\begin{array}{l}\text { Magatama, a curved bead. } 3.5 \mathrm{~cm} \\
\text { in length. Found in a tomb at } \\
\text { Sugu, Fukuoka prefecture }\end{array}$ & Lead phosphate \\
\hline $5 *$ & $\begin{array}{l}\text { Kudatama, a cylindrical bead. } \\
5 \mathrm{~mm} \text { in diameter and } 23 \mathrm{~mm} \\
\text { in length. The same locality as } \\
\text { the object no. } 4\end{array}$ & Lead phosphate \\
\hline
\end{tabular}

Table II. X-ray diffraction data

No. 3 Mirror

\begin{tabular}{r|c|c|c}
\hline & Visual intensity & $\mathrm{d}[$ found $]$ & $\mathrm{d}\left[\mathrm{PbCO}_{3}\right]$ \\
\hline 1 & vw & $4.46 \AA$ & $4.40 \AA$ \\
2 & $\mathrm{vw}$ & 4.15 & $4.24 ?$ \\
3 & $\mathrm{vs}$ & 3.54 & 3.56 \\
4 & $\mathrm{w}$ & 3.12 & $3.05 ?$ \\
5 & $\mathrm{w}$ & 2.81 & \\
6 & $\mathrm{vs}$ & 2.49 & 2.47 \\
7 & $\mathrm{vw}$ & 2.16 & 2.19 \\
8 & $\mathrm{~s}$ & 1.07 & 2.07 \\
9 & $\mathrm{~m}$ & $1.91_{5}$ & 1.99 \\
10 & $\mathrm{~m}$ & 1.84 & 1.91 \\
11 & $\mathrm{~s}$ & 1.78 & 1.79 \\
12 & $\mathrm{vw}$ & 1.62 & 1.62 \\
13 & $\mathrm{w}$ & 1.57 & 1.58 \\
14 & $\mathrm{w}$ & 1.49 & 1.55 \\
15 & $\mathrm{w}$ & 1.47 & 1.40 \\
16 & $\mathrm{vw}$ & & \\
17 & $\mathrm{vw}$ &
\end{tabular}

No. 5 Kudatama

\begin{tabular}{c|c|c|c}
\hline & Visual intensity & $\mathrm{d}[$ found $]$ & $\mathrm{d}\left[\mathrm{Pb}_{3}\left(\mathrm{PO}_{4}\right)_{2}\right]$ \\
\hline 1 & $\mathrm{~s}$ & $4.13 \AA$ & $(4.03) \AA$ \\
2 & $\mathrm{w}$ & 3.67 & 3.61 \\
3 & $\mathrm{vw}$ & 3.23 & 3.18 \\
4 & $\mathrm{~s}$ & 2.93 & 2.91 \\
5 & $\mathrm{vvw}$ & 2.48 & \\
6 & $\mathrm{w}$ & 2.06 & 2.02 \\
7 & $\mathrm{w}$ & 1.95 & $\{1.96$ \\
& & 1.54 & 1.51 \\
8 & $\mathrm{w}$ & 1.52 & 1.54 \\
\hline
\end{tabular}

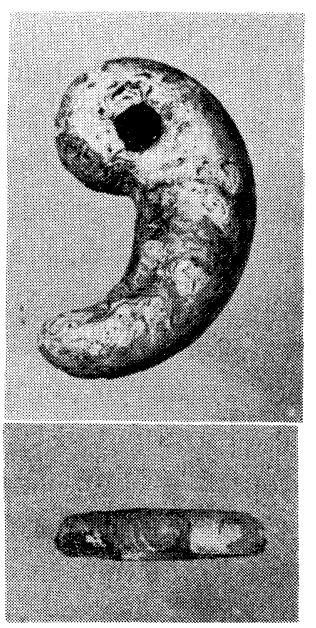

Magatama of glass no. 4 and Kudatama of glass similar to glass no. 5 (Natural size)

vs: very strong, $\mathrm{s}$ : strong, $\mathrm{m}$ : medium, w: weak, vw: very weak, vvw: faint 
As might be expected, lead carbonate was found to be the principal corrosion product of lead glass objects if unpublished results are taken into account. It was formed by the chemical action of salts and gases like carbon dioxide dissolved in water. The formation of lead sulfate is also supposed to be due to the action of water containing a significant amount of sulfate ion. On the other hand lead phosphate is of rather rare occurrence and it might have been formed under a special condition, that is, in direct contact with corpses with which these glass objects were buried. Apparently lead phosphate is the product of chemical reactions between lead glass and calcium phosphate which is the main constituent of bone, and other phosphates contained in human body.

It is to be noted that a similarity is apparent between the corrosion products of lead glass and those of bronze objects. Carbonates are most frequently found in both corroded glass and bronze objects, lead carbonate for the former, and basic copper carbonates, malachite and azurite for the latter. Copper sulfate is not found in the corrosion products of bronze because it is soluble in water in contrast to insoluble lead sulfate. The presence of copper phosphate in the corroded layer of a mirror of the Warring States period has already been noticed in 1939 by Professor Shibata and Dr. Shinoda. ${ }^{2)}$ They explained the occurrence of copper phosphate as the result of chemical reactions between bronze and the decomposition products of corpse.

In the corrosion products of bronze objects cuprite, atacamite, and other minerals were found in addition to malachite and azurite. ${ }^{3)}$ In glass objects, however, no lead compounds other than carbonate, sulfate, and phosphate have so far been found, although lead oxides and chloride were identified for lead objects excavated at Athens, Greece. ${ }^{4)}$

Grateful acknowledgment is made to Dr. Sueji Umehara for placing the valuable glass objects at our disposal.

\section{References}

1) J. D. Hanawalt, H. W. Rinn, and L. K. Frevel: Ind. Eng. Chem. Anal. Edition, 10, 457 (1938).

2) Y. Shibata and S. Shinoda: Kokka, no. 589, 387 (1939).

3) E. R. Caley: Proc. Amer. Phil. Soc., 84, 689 (1941). R. J. Gettens: Bull. Fogg Museum, Harvard Univ., 11, 16 (1949); J. Chem. Education, 28, 67 (1951).

4) E. R. Caley: Studies in Conservation, 2, 49 (1955). 